\title{
Toxicity Studies on Aqueous-Methanol Pod Extract of Vigna unguiculata (Cowpea) in Wistar Strain Albino Rats
}

\author{
${ }^{* 1}$ A. F. Okwunakwe, ${ }^{1}$ Y. Saidu, ${ }^{2 M}$. Achor , ${ }^{1}$ S. A. Isa, ${ }^{1}$ A. Y. Abbas, ${ }^{1}$ L.S. Bilbis \\ ${ }^{1}$ Department of Biochemistry, Usmanu Danfodiyo university, P.M.B 2346, Sokoto, Nigeria \\ 2Department of Pharmacy, Usmanu Danfodiyo university, P.M.B 2346, Sokoto, Nigeria
}

[*Corresponding Author: E-mail: adaokw@yahoo.com]

\begin{abstract}
Herbal preparation of Vigna unguiculata (cowpea) pod has long been used by a group of Hausa people from northern Nigeria called Yan tauri performers and traditional healers. This study was conducted to evaluate the toxicological effect of the extract in Wistar strain albino rats using biochemical, haematological and histopathological indices of toxicity. Acute toxicity $\left(\mathrm{LD}_{50}\right)$ and sub-chronic toxicity studies were determined using the method developed by OECD. Twenty-five (25) rats were grouped into five(5) consisting of five(5) rats each, one of the groups served as control., Group II, III, IV and V were orally administered with the extract at a daily dose of $400 \mathrm{mg} / \mathrm{kg}, 800 \mathrm{mg} / \mathrm{kg}, 1200 \mathrm{mg} / \mathrm{kg}$ and $1600 \mathrm{mg} / \mathrm{kg}$ of the extract, respectively for 28 days. The LD 50 of the extract was greater than 5000 $\mathrm{mg} / \mathrm{kg}$ and its oral administration for 28 days did not produce significant changes $(P>0.05)$ on biochemical and haematological indices. Histopathological evaluation revealed mild widening of Bowman's capsule of animals administered with $1200 \mathrm{mg} / \mathrm{kg}$ and $1600 \mathrm{mg} / \mathrm{kg}$ of the extract. It can thus be concluded that the pod is non-toxic.
\end{abstract}

Keywords: Vigna unguiculata pod, Yan tauri performers, Aqueous-methanol extract, Acute and subchronic toxicity

\section{INTRODUCTION}

Pod is the long narrow outer case holding the seeds of a legume plant such as common beans, pea or vanilla (FAOUN, 2013). Green cowpea pods are cooked as a vegetable (Chikwendu et al., 2014). Dried cowpea pod are rehydrated before cooking and can serve as browse for livestock (RCP, 2012). It is also taken as a diuretic to increase urine production (Weiss and Fintelmann, 2000). Cowpea pods are also believed to have antibacterial, antiinflammatory, antioxidant (Subramanian and Leelavinothan, 2002), antiparasitic, antiviral, cleansing and detoxifying, emollient and gasrelieving properties (Rafi and Vastano, 2002). Cowpea pods are a source of dietary fibre (Romero-Arenas et al., 2013). It is used for the treatment of diabetes (Roman-Ramos et al., 1995), obesity, arthritis, gout, oedema, hypertension, constipation, kidney and bladder disorders (Verhelst, 2010). Modified and unmodified cowpea pod can be used for effluent water treatment (Adediran et al., 2005; Mubo et al., 2015).
Yan tauri performers (tough-skin men) found in the northern part of Nigeria are people who cannot be cut or pierced by a knife or any metal and when cut they do not bleed to death. They are known to drink concoction prepared with dry cowpea pods known as kowa in Hausa language. According to Gidley (1967), Yan tauri performers are public entertainers.

Scientific evaluation of medicinal plants is important to assess toxicity risks associated with the use of herbal preparations (Toma et al., 2009). Owing to the wide consumption of cowpea pod by the Yan tauri performers; this study was designed to examine the effect of cowpea pod on the haematological and histopathological indices of the liver and kidney of rats.

\section{MATERIALS AND METHODS Chemicals and Reagents}

All chemicals and reagents used in this study were of analytical grade.

\section{Sample Collection and Identification}

The Cowpea pod was obtained from farmland in Gidan Tudu village near Usmanu Danfodiyo 
University, Sokoto. The plant was identified by a Taxonomist in the Botany unit, Biological Science Department, Usmanu Danfodiyo University, Sokoto and a voucher specimen was deposited at the herbarium of the same department with a voucher number UDUH/ANS/0152. The dried sample was pulverized into a fine powder using a mechanical blender. It was then macerated in an aqueous-methanol solvent (70:30; methanol and water) at room temperature with shaking at regular intervals for 72 hours after which it was filtered. The filtrate was then dried using the drying cabinet.

\section{Experimental Animals}

The albino (Wistar) rats that were used in this study were purchased from the National Veterinary Research Institute (NVRI) Vom, Jos. The experimental rats were housed in cages and fed with standard pellet diet (Vital Feeds Ltd, Nigeria) and were allowed free access to feed and water (ad libitum) throughout the experiment. The rats were kept in the animal house of the Department of Biochemistry, Usmanu Danfodiyo University, Sokoto for two (2) weeks to acclimatize before the commencement of the experiment.

\section{Phytochemical Screening}

Phytochemical constituents of the pod were determined using the methods of Harborne (1973), Trease and Evans (1989), El-Olemyl et al. (1994) and Sofowora (1993).

\section{Acute Oral Toxicity Study (Determination of $\mathrm{LD}_{50}$ )}

The acute oral toxicity study was carried out using the method developed by the Organization for Economic and Cultural Development, 2001 (OECD, 2001). Five randomly selected animals were used for the experiment. Each animal was dosed, one at a time at $72 \mathrm{hrs}$ intervals. The extract was administered at $5000 \mathrm{mg} / \mathrm{kg}$ body weight in a single dose. For the first $8 \mathrm{hrs}, 14 \mathrm{hrs}, 24 \mathrm{hrs}$, $48 \mathrm{hrs}$ and $72 \mathrm{hrs}$ signs of toxicity like tremors, itching, depression, weakness, food and water refusal, salivation and death were observed.
The animals were observed further for 14 days for any signs of delayed toxicity.

\section{Sub-chronic Oral Toxicity Study}

Sub-chronic oral toxicity study was carried out according to the Organization for Economic and Cultural Development (OECD, 2008) method. Twenty five albino rats were grouped into five groups containing five animals each. Group 1 served as the control while 2-5 were administered with $400 \mathrm{mg} / \mathrm{kg}, 800 \mathrm{mg} / \mathrm{kg}, 1200$ $\mathrm{mg} / \mathrm{kg}$ and $1600 \mathrm{mg} / \mathrm{kg}$, respectively of the extract on a daily basis for 28 days. The extract was administered to the animals orally via cannula. At the end of the experimental period, the animals were anesthetized and blood, liver and kidney tissues were collected for biochemical, haematological and histopathological assessment, respectively. For the blood, the neck area was cleared of fur and skin to expose the jugular veins. These veins were cut sharply with a sterile scalpel blade and the rats were held head downwards and allowed to bleed into clean dry sample bottles. The serum was collected using Pasteur pipette after centrifugation at $4000 \mathrm{rpm}$ for 5 minutes and kept in labelled sample bottles at $4{ }^{\circ} \mathrm{C}$ until required for analysis.

Each of the biochemical parameters was carried out using standard methods while haematological parameters were analysed using an automated haematological analyzer (Theml et al., 2004).

\section{Histopathological Study}

The kidney and liver were fixed in $10 \%$ buffered formalin for 72 hours. The tissues were then dehydrated in alcohol of graded concentrations and embedded in paraffin. Embedded tissues were cut into sections of $5 \mu \mathrm{m}$ thick and these were stained with hematoxylin and eosin for photo microscopic assessment and placed on a clean labelled microscope glass slide. The slide was mounted on an electric light microscope for examination of any possible histopathological features. Photomicrographs of the samples were then taken (Drury et al., 1967). 


\section{Data Analysis}

The results were expressed as mean \pm standard error of the mean (SEM). Using the statistical package SPSS version 20 software, the difference between means was carried out using one-way analysis of variance (ANOVA) followed by Dunnett comparison test. Histopathological results were presented using a plate which was generated from lesion scoring: the difference between means was carried out using the Kruskal-Wallis comparison test. Values were considered statistically significant at $P<0.05$.

\section{RESULTS AND DISCUSSION}

Vigna unguiculata pod contains flavonoids, alkaloids, saponins, tannins, steroids, volatile oils, resins, glycosides, saponin glycosides, balsams and terpenes (Table 1). This agrees with the findings of Chikwendu et al. (2014), Tavares et al. (2015) and Seidu et al. (2014) who have reported the presence of these components and others in the members of Fabaceae family. The presence of phytochemicals in extracts of plants is responsible for pharmacological activities observed in biological systems, which may probably support claims by traditional healers. The studies of lgwo-Ezikpe et al. (2013) and Wonghirundecha et al. (2014) demonstrated the antioxidant and antimicrobial potentials of phytochemicals present in ethanol extract of Parkia biglobosa (African locust bean) pod and Parkia speciosa (stink bean) pod, respectively. Determination of acute toxicity, $L_{50}$ is usually the first step in the evaluation of the toxic characteristics of a substance (Ogbuehi et al., 2015). This study showed that the $L_{50}$ of the aqueous-methanol pod extract of $V$. unguiculata was greater than $5000 \mathrm{mg} / \mathrm{kg}$ as shown in Table 2. No mortality and visible signs of toxicity like tremors, itching, depression, weakness, bulging of the eye, hair loss, food and water refusal and salivation were observed over 14 days, indicating that it is non-toxic at "acute dose. In other words, acute exposure to high doses of the aqueous-methanol extract of V. unguiculata pod is non-toxic."
According to the toxicity scale of Hodge and Sterner, any compound with an oral $\mathrm{LD}_{50}$ above $5000 \mathrm{mg} / \mathrm{kg}$ should be considered practically non-toxic (Hodge and Sterner, 2005).

Table 1: Qualitative phytochemical composition of Vigna unguiculata pod

\begin{tabular}{lc}
\hline PHYTOCHEMICAL & STATUS \\
\hline Flavonoids & + \\
Condensed tannins & + \\
Saponins & + \\
Alkaloids & + \\
Cardiac glycosides & $\mathrm{ND}$ \\
Steroids & + \\
Saponin glycosides & + \\
Balsams & + \\
Anthraquinones & $\mathrm{ND}$ \\
Volatile oils & + \\
Glycosides & + \\
Terpenes & + \\
Resins & + \\
\hline
\end{tabular}

Key: + = present, ND = not detected

Table 2: Acute toxicity profile of aqueousmethanol extract of Vigna unguiculata pod in albino rats

\begin{tabular}{llll}
\hline $\begin{array}{l}\text { DOSE } \\
(\mathrm{mg} / \mathrm{kg})\end{array}$ & GROUP & $\begin{array}{l}\text { NUMBER } \\
\text { of } \\
\text { ANIMAL }\end{array}$ & $\begin{array}{l}\text { NUMBER } \\
\text { of } \\
\text { DEATH }\end{array}$ \\
\hline $\mathbf{5 0 0 0}$ & $\mathrm{I}$ & 1 & 0 \\
$\mathbf{5 0 0 0}$ & II & 1 & 0 \\
$\mathbf{5 0 0 0}$ & III & 1 & 0 \\
$\mathbf{5 0 0 0}$ & IV & 1 & 0 \\
$\mathbf{5 0 0 0}$ & $\mathrm{V}$ & 1 & 0 \\
\hline
\end{tabular}

$\mathrm{LD}_{50}>5000 \mathrm{mg} / \mathrm{kg}$

Results presented in Tables 3, 4 and 5 indicate the non-toxicity of the pod after carrying out sub-chronic toxicity study for 28 days. Umaru et al. (2015) similarly reported that administration of aqueous pod extract of Acacia nilotica to experimental rats for 21 days did not significantly $(p>0.05)$ alter the levels of RBC, $\mathrm{Hb}$ and PCV. However, prolonged 
Okwunakwe et al. Toxicity Studies on Aqueous-Methanol Pod Extract of Vigna unguiculata...

administration of the extract may adversely affect the kidneys. This may explain the mild degeneration of the kidney (Table 6 , Plate $1 \mathrm{~A}$ -

E) observed at high dose $(1200 \mathrm{mg} / \mathrm{kg}$ and 1600

$\mathrm{mg} / \mathrm{kg}$ ).

Table 3: Sub-chronic Toxicity Evaluation of aqueous-methanol extract of Vigna unguiculata pod on Liver function indices of experimental rats

\begin{tabular}{llllll}
\hline PARAMETER & CONTROL & $\mathbf{4 0 0} \mathbf{~ m g} / \mathbf{k g}$ & $\mathbf{8 0 0} \mathbf{~ m g} / \mathbf{k g}$ & $\mathbf{1 2 0 0} \mathbf{~ m g} / \mathbf{k g}$ & $1600 \mathbf{~ m g} / \mathbf{k g}$ \\
\hline ALT (U/L) & $20.00 \pm 5.38$ & $29.40 \pm 11.17$ & $32.33 \pm 11.85$ & $38.25 \pm 11.59$ & $36.33 \pm 1.76$ \\
AST (U/L) & $61.00 \pm 3.99$ & $62.80 \pm 7.41$ & $70.33 \pm 10.68$ & $65.25 \pm 4.05$ & $71.33 \pm 9.84$ \\
TP (g/dL) & $9.58 \pm 0.41$ & $11.65 \pm 0.91$ & $12.09 \pm 0.76$ & $9.51 \pm 0.87$ & $10.32 \pm 2.17$ \\
ALB (g/dL) & $5.20 \pm 0.36$ & $5.96 \pm 0.29$ & $5.70 \pm 0.15$ & $5.50 \pm 0.32$ & $4.19 \pm 0.51$ \\
G (g/dL) & $4.38 \pm 0.51$ & $5.69 \pm 1.09$ & $6.40 \pm 0.85$ & $4.01 \pm 1.12$ & $6.13 \pm 2.03$ \\
A/G RATIO & $1.28 \pm 0.22$ & $1.29 \pm 0.32$ & $0.92 \pm 0.13$ & $1.78 . \pm 0.35$ & $0.87 \pm 0.28$ \\
DB (mg/dL) & $2.67 \pm 0.66$ & $3.34 \pm 0.37$ & $2.22 \pm 0.77$ & $1.69 \pm 0.29$ & $1.62 \pm 0.30$ \\
TB (mg/dL) & $3.31 \pm 0.61$ & $3.97 \pm 0.41$ & $2.90 \pm 0.47$ & $2.52 \pm 0.40$ & $2.55 \pm 0.45$
\end{tabular}

Values are mean \pm standard error of the mean $(n=5)$. Values were not significantly different $(p>0.05)$ when compared to control group (one-way ANOVA followed by Dunnett comparison test using SPSS version 20). ALT- Alanine Amino Transferase, AST- Aspartate Amino Transferase, TP- Total Protein, ALB- Albumin, G- Globulin, A/G- albumin:globulin, DB- Direct Bilirubin, TB- Total Bilirubin.

Table 4: Kidney function indices of rats administered with sub-chronic doses of aqueous-methanol extract of Vigna unguiculata pod

\begin{tabular}{lllllll}
\hline $\begin{array}{l}\text { Group } \\
\text { (mg/kg) }\end{array}$ & $\begin{array}{l}\text { UREA } \\
(\mathbf{m g} / \mathrm{dL})\end{array}$ & $\begin{array}{l}\text { CRT } \\
(\mathrm{mg} / \mathrm{dL})\end{array}$ & $\begin{array}{l}\mathrm{UA} \\
(\mathrm{mg} / \mathrm{dL})\end{array}$ & $\begin{array}{l}\mathrm{Cl}^{-} \\
(\mathrm{mMol} / \mathrm{L})\end{array}$ & $\begin{array}{l}\mathrm{K}^{+} \\
(\mathrm{mMol} / \mathrm{L})\end{array}$ & $\begin{array}{l}\mathrm{HCO}_{3}^{-} \\
(\mathrm{mMol} / \mathbf{L})\end{array}$ \\
\hline Control & $15.71 \pm 0.82$ & $0.13 \pm 0.04$ & $3.13 \pm 0.30$ & $3.40 \pm 0.19$ & $1.24 \pm 0.10$ & $3.50 \pm 0.27$ \\
$\mathbf{4 0 0}$ & $16.37 \pm 1.21$ & $0.14 \pm 0.02$ & $2.46 \pm 0.72$ & $3.50 \pm 0.16$ & $1.20 \pm 0.14$ & $3.60 \pm 0.62$ \\
$\mathbf{8 0 0}$ & $13.99 \pm 0.23$ & $0.13 \pm 0.04$ & $2.21 \pm 0.38$ & $3.67 \pm 0.44$ & $1.26 \pm 0.07$ & $3.67 \pm 0.17$ \\
1200 & $12.99 \pm 0.78$ & $0.13 \pm 0.02$ & $2.64 \pm 0.71$ & $3.75 \pm 0.14$ & $1.09 \pm 0.06$ & $3.38 \pm 0.31$ \\
1600 & $12.86 \pm 0.52$ & $0.13 \pm 0.02$ & $2.26 \pm 0.72$ & $3.83 \pm 0.17$ & $1.13 \pm 0.07$ & $3.67 \pm 0.17$
\end{tabular}

Values are mean \pm standard error of the mean $(n=5)$. The values were not significantly different $(p>0.05)$ when compared with the control group (one-way ANOVA followed by Dunnett comparison test using SPSS version 20). CRTCreatinine, UA- Uric Acid, $\mathrm{K}^{+}$- Potassium ion, $\mathrm{Cl}-$ Chloride ion and $\mathrm{HCO}_{3}-$-Bicarbonate ion.

Table 5: Haematological indices of rats administered with sub-chronic doses of aqueous-methanol extract of Vigna unguiculata pod

\begin{tabular}{llllll}
\hline PARAMETERS & CONTROL & $400 \mathrm{mg} / \mathrm{kg}$ & $800 \mathrm{mg} / \mathrm{kg}$ & $1200 \mathrm{mg} / \mathrm{kg}$ & $1600 \mathrm{mg} / \mathrm{kg}$ \\
\hline WBC $\left(10^{3} / \mathrm{mm}^{3}\right)$ & $12.20 \pm 1.52$ & $8.69 \pm 1.22$ & $8.42 \pm 1.55$ & $8.02 \pm 1.58$ & $10.93 \pm 1.01$ \\
RBC $\left(10^{6} / \mathrm{mm}^{3}\right)$ & $5.88 \pm 0.73$ & $7.39 \pm 0.26$ & $7.44 \pm 0.01$ & $7.27 \pm 0.48$ & $6.78 \pm 0.58$ \\
HGB $(\mathrm{g} / \mathrm{dL})$ & $12.18 \pm 0.84$ & $13.96 \pm 0.47$ & $14.13 \pm 0.19$ & $13.38 \pm 1.07$ & $12.73 \pm 1.27$ \\
MCHC (g/dL) & $34.22 \pm 3.15$ & $31.14 \pm 1.80$ & $31.97 \pm 0.54$ & $30.68 \pm 2.72$ & $33.90 \pm 0.59$ \\
MCH (pg) & $22.16 \pm 3.54$ & $18.90 \pm 0.28$ & $18.97 \pm 0.27$ & $18.33 \pm 0.26$ & $18.77 \pm 0.70$ \\
MCV (fL) & $63.48 \pm 3.73$ & $61.42 \pm 3.54$ & $59.33 \pm 0.35$ & $61.20 \pm 5.52$ & $55.40 \pm 1.57$ \\
PCV (\%) & $41.68 \pm 1.29$ & $42.52 \pm 1.84$ & $44.13 \pm 0.28$ & $40.08 \pm 3.19$ & $37.63 \pm 3.92$ \\
\hline
\end{tabular}


Nigerian Journal of Basic and Applied Science (December, 2020), 28(2): 01-09

\begin{tabular}{llllll}
\hline PLT (103/mm $)$ & $698.60 \pm 47.14$ & $587.60 \pm 21.22$ & $586.33 \pm 18.68$ & $540.75 \pm 91.69$ & $604.67 \pm 51.56$ \\
MPV (fL) & $7.34 \pm 0.47$ & $7.04 \pm 0.16$ & $6.83 \pm 0.09$ & $7.05 \pm 0.20$ & $6.80 \pm 0.23$ \\
PDW (fL) & $13.14 \pm 0.57$ & $12.86 \pm 0.47$ & $12.47 \pm 0.52$ & $12.95 \pm 0.16$ & $13.00 \pm 0.42$ \\
PCT (\%) & $0.41 \pm 0.11$ & $0.41 \pm 0.07$ & $0.40 \pm 0.01$ & $0.38 \pm 0.06$ & $0.41 \pm 0.10$ \\
P-LCR (\%) & $7.72 \pm 0.49$ & $9.84 \pm 1.41$ & $8.10 \pm 0.69$ & $9.08 \pm 0.67$ & $7.80 \pm 1.84$
\end{tabular}

Values are mean \pm standard error of the mean $(n=5)$. The values were not significantly $(p>0.05)$ different when compared with the control using one-way ANOVA, SPSS version 20. WBC - white blood cell, RBC - red blood cell, HGB - haemoglobin, MCHC - mean cell haemoglobin concentration, $\mathrm{MCH}$ - mean cell haemoglobin, MCV - mean corpuscular volume, PCV packed cell volume, PLT - platelet, MPV - mean platelet volume, PDW - platelet distribution width, PCT- platelet haematocrit, P-LCR - platelet larger cell ratio.

Mild widening of the Bowman's capsule (Plate $1 \mathrm{D}$ and $1 \mathrm{E}$ ) observed in the kidney of animals administered with 1200 and $1600 \mathrm{mg} / \mathrm{kg}$ of the extract may be that the morphological architecture of the kidney has to be extensively deranged before any significant aberration could be detected biochemically (Ghasi et al., 2012).

Widened Bowman's capsule may be due to tissue anoxia (Stark, 1980) or renal vasoconstriction in response to nephrotoxicant (Schellman, 1995). Akanmu et al. (2004) reported the histopathological examination of kidneys of rats treated with $1000 \mathrm{mg} / \mathrm{kg}$ of Cassia fistula pods extract showed wide Bowman's capsule and wide proximal tubules. According to Kalu et al. (2011), excess consumption of phytochemicals rich in saponins and alkaloids can produce undesirable side effects and could inhibit certain enzyme activities such as adenosine monophosphate.
Table 6: Histopathological results of the kidney of rats administered with sub-chronic doses of aqueous methanol extract of Vigna unguiculata pod

\begin{tabular}{ccc}
\hline $\begin{array}{c}\text { DOSES } \\
\text { (mg/kg) }\end{array}$ & \multicolumn{2}{c}{ LESION SCORE (Mean ranks) } \\
& DEGENERATION & HAEMORRHAGE \\
\hline Control & $5.50^{\mathrm{a}}$ & $9.50^{\mathrm{a}}$ \\
400 & $5.50^{\mathrm{a}}$ & $9.50^{\mathrm{a}}$ \\
800 & $15.00^{\mathrm{b}}$ & $12.83^{\mathrm{a}}$ \\
1200 & $15.00^{\mathrm{b}}$ & $12.00^{\mathrm{a}}$ \\
1600 & $16.67^{\mathrm{c}}$ & $9.50^{\mathrm{a}}$ \\
\hline
\end{tabular}

Mean ranks having different superscript in the same column are significantly different $(p<0.05)$ (KruskalWallis comparison test using SPSS version 20).

\section{CONCLUSION}

The aqueous-methanol pod extract of Vigna unguiculata was studied for its acute and subchronic toxicity in Wistar strain albino rats. The results showed that the extract was non-toxic and it has no effect on biochemical and haematological parameters but the mild widening of the Bowman's capsule was observed in the kidney of animals administered with 1200 and $1600 \mathrm{mg} / \mathrm{kg}$ of the extract. Further studies on the chronic toxicity of aqueous-methanol pod extract of $V$. unguiculata should be carried out. 
Okwunakwe et al. Toxicity Studies on Aqueous-Methanol Pod Extract of Vigna unguiculata...

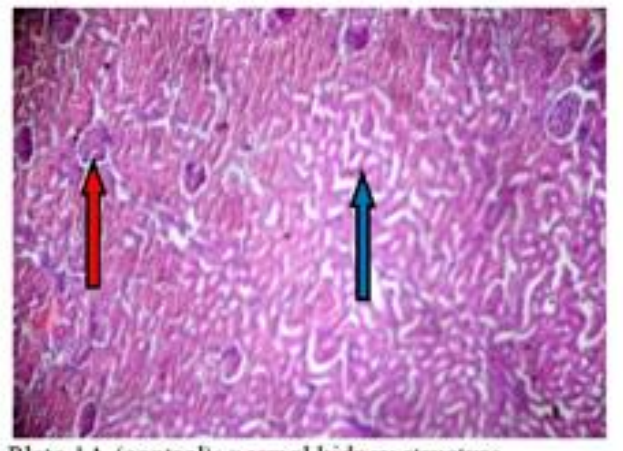

Plate IA (control): normal kidney structure

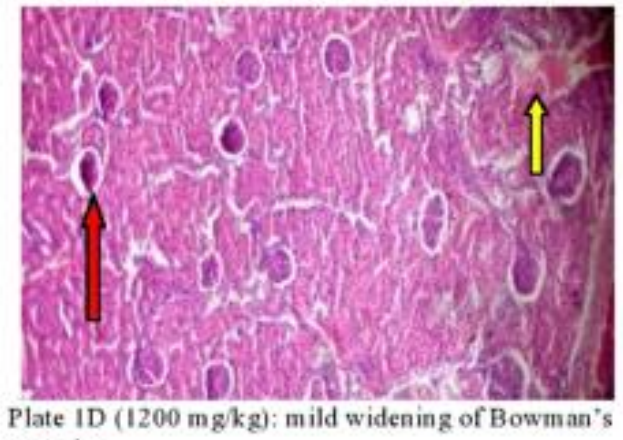

capsule

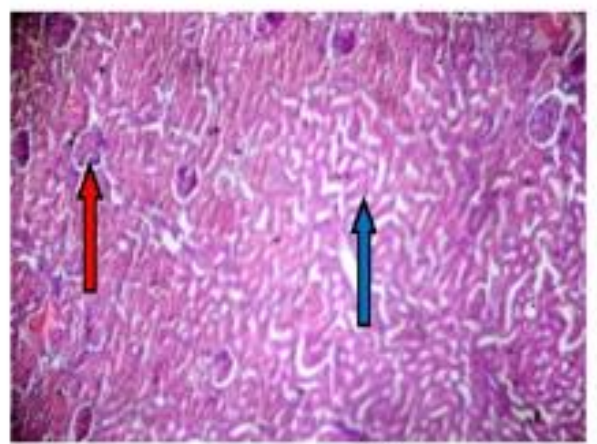

Plate IB ( $400 \mathrm{mg} / \mathrm{kg})$; normal kidney structure

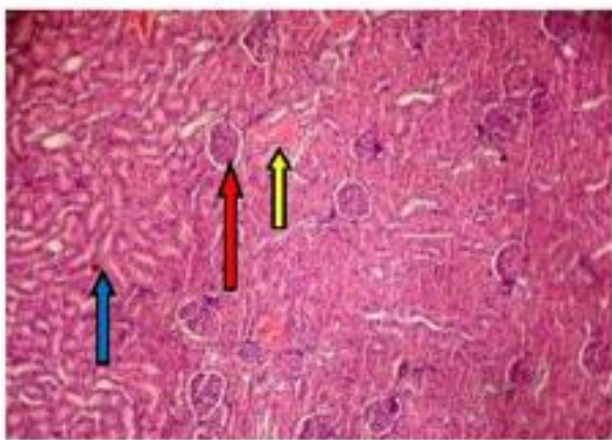

Plate IC ( $800 \mathrm{mg} / \mathrm{kg})$ : mild haemorrhage

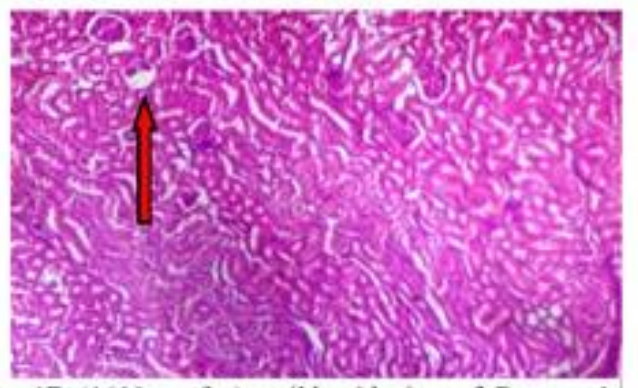
Plate IE $(1600 \mathrm{mg} / \mathrm{kg})$ : mild widening of Bowman's capsule

Plate 1A-E: photomicrograph of rat kidney administered with sub-chronic doses of aqueous-methanol extract of Vigna unguiculata pod (H\&E stain, x 100 magnification). Red arrow - glomerulus, blue arrow - collecting duct, yellow arrow - haemorrhage 
Nigerian Journal of Basic and Applied Science (December, 2020), 28(2): $01-09$

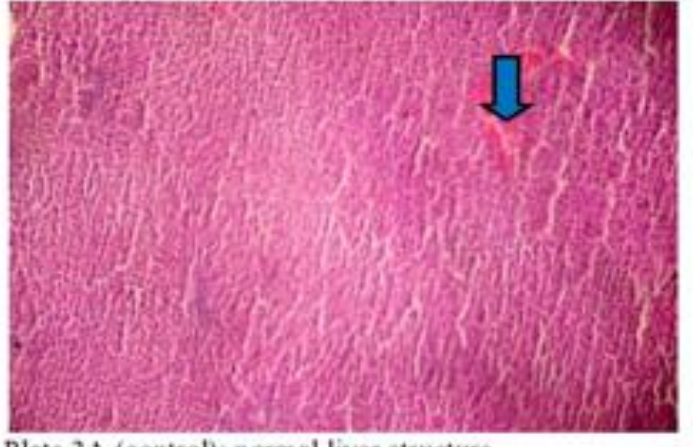

Plate $2 \mathrm{~A}$ (control): normal liver structure

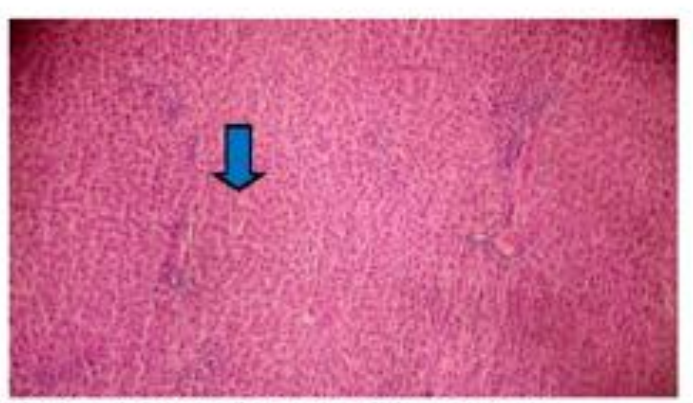

Plate 2D (1200 mg/kg): normal liver structure

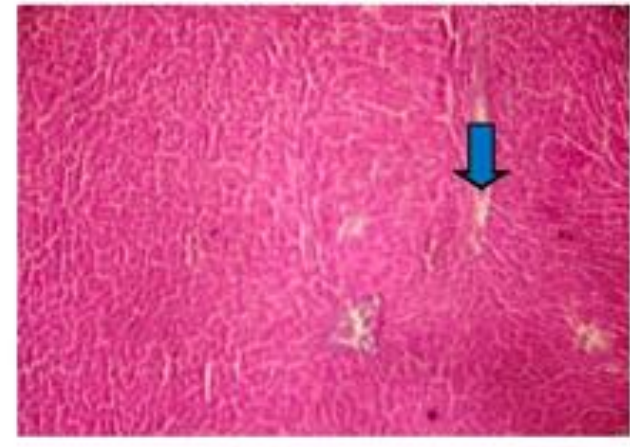

Plate 2B (400 m g/k $)$ : normal liver structure

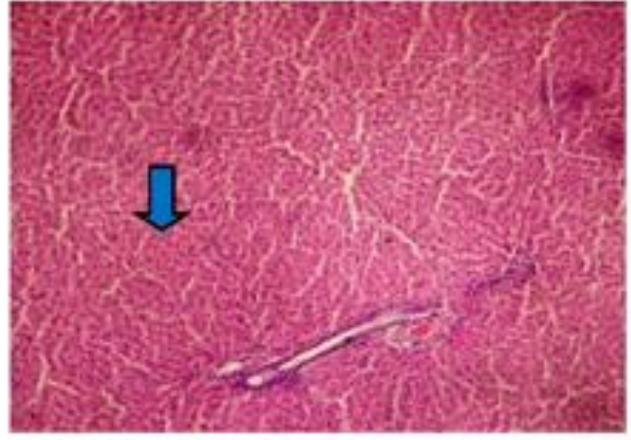

Plate 2C ( $800 \mathrm{mg} / \mathrm{kg})$ : normal liver structure

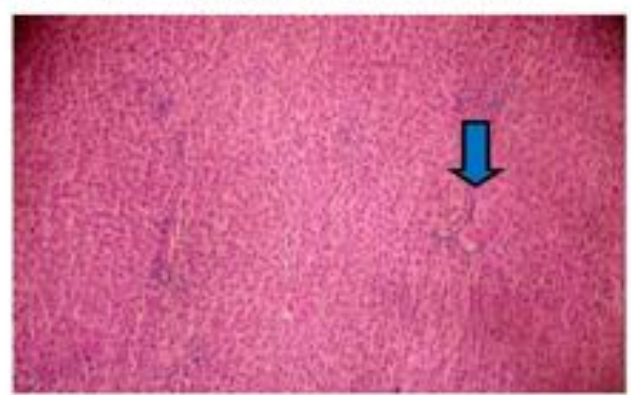

Plate 2E (1600 mg/kg): normal liver structure

Plate 2A-E: photomicrograph of rat liver administered with sub-chronic doses of aqueous-methanol extract of Vigna unguiculata pod (H\&E stain, $x 100$ magnification). Blue arrow - hepatocyte 


\section{REFERENCES}

Adediran, G.O., Tella, A.C. and Mohammed, H.A. (2005). Sorption of some heavy metal ions chemically modified bean-husks. Science Focus, 10(2):72-78.

Akanmu, M.A., Iwalewa, E.O., Elujoba, A.A., \& Adelusola, K.A. (2004). Toxicity potentials of Cassia fistula fruits as laxative with reference to senna. African Journal of Biomedical Research, 7:23-26.

Chikwendu, J.N., Igbatim, A.C. and Obizoba, I.C. (2014). Chemical composition of processed cowpea tender leaves and husks. International Journal of Scientific and Research Publications, 4(5):22503153.

Drury, R.A., Wallington, E.A., \& Cameron, R. (1967); Carletons histological technique. $4^{\text {th }}$ ed. Oxford University press.New York, 48-66.

El-Olemyl, M.M., Fraid, J.A., \& Abdulfattah, A.A. (1994). Experimental photochemistry. A laboratory manual Afifi, Abdel Fattah, A comp. IV King Saud university press, UK, 1-134.

FAOUN (Food and Agriculture Organization of the United Nations) (2013); Definition and classification of commodities, 4, Pulses and derived products.

Ghasi, S., Odurukwe, O.,\& Ufelle, S. (2012). Appraisal of the kidney status of the rat model to sub-acute treatment with piperazine citrate. Pharmacologia, 3(8):306-312.

Gidley, C.G.B. (1967). Yan kamanci-the craft of the Hausa comedians. African Language Studies, 8:52-81.

Harborne, J.B. (1973); Phytochemical methods, London. Chapman and Hall, Ltd., 49-80.

Hodge, A., \& Sterner, B. (2005). Toxicity Classes In: Canadian Centre for Occupational Health and safety, 12-17.

Igwo-Ezikpe, M.N., Ogbunugafor, H.A., Gureje, A.P., \& Ezeonwumelu, I.J. (2013). Phytochemical, antioxidant and antimicrobial properties of Parkia biglobosa (african locust bean) pods. The Bioscientist, 1(2):182-191.

Kalu, F.N., Ogugua, V.N.I., Ujowumdi, C.O., \& Chinekeokwu, C.R.K. (2011). Chemical composition and acute toxicity studies on the aqueous extract of Combretum dolichopentalum leaf in swiss albino mice. Journal of Science Research, 1:18.

Mubo, A., Edet, W.N., \& Peter, K.O. (2015). The use of unmodified, EDTA and oxalic acid modified beans husk as hazardous remediation agent. Journal of Environmental Science, Toxicology and Food Technology, 9(6):1-9.

OECD, (2001). OECD Guidelines for testing chemicals. Organisation for economic cooperation and development: Acute toxicity - up and down procedure. No., 425:1-26.

OECD, (2008). OECD Guidelines for testing chemicals. Organisation for economic cooperation and development: Test No. 407: repeated dose 28-days oral toxicity study in rodents. Paris: OECD publishing, 10.

Ogbuehi, I.H., Ebong, O.O., \& Obianime, A.W. (2015). Oral acute toxicity $\left(L_{50}\right)$ study of different solvent extracts of Abrus precatorius Linn leaves in wistar rats. European Journal of Experimental Biology, 5(1):18-25.

Rafi, M.M., \& Vastano, B.C. (2002); Novel polyphenol molecule isolated from licorice root (Glycrrhizaglabra) induces apoptosis, G2/M cell cycle arrest, and Bcl-2 phosphorylation in tumor cell lines. Journal of Agricultural and Food Chemistry, 50:677-684.

RCP (Resistant Cowpea Project) (2012); Pod borer resistant cowpea: potentials and constraints. Cowpea for food and poverty alleviation.

Roman-Ramos, R., Flores-Sanoz, J.L., \& Alarcon, A.F.J. (1995); Antihyperglycemic effect of some edible plants. Journal of Ethnopharmacology, 48:25.

Romero-Arenas, O., Damián, H.M.A., Rivera, T.J.A., Báez, S.A., Huerta, L.M., \& Cabrera, H.E. (2013); The nutritional value of beans (Phaseolus vulgaris L.) and its importance for feeding of rural communities in Puebla-Mexico. International Research Journal of Biological Sciences, 2(8):59-65.

Schellman, R.G. (1995); Toxic responses of the kidney. Casarett and Doull's toxicology. The basic science of poisons. Klaassen 
CD ed. (7th) McGraw Hill Companies Inc, New York, NY: 591-597.

Seidu, K.T., Osundahunsi, O.F., Olaleye, M.T., \& Oluwalana, I.B. (2014); Chemical composition, phytochemical constituents and antioxidant potentials of lima bean seeds coat. Annals of Food Science and Technology, 15(2):288-296.

Sofowora, A. (1993); African medicinal plants. University of Ife Press (Nig). $3^{\text {rd }}$ Edition, 21-30.

Stark, J.L. (1980); BUN/creatinine: your keys to kidney function. Nursing, 10:33-38.

Subramanian, V., \& Leelavinothan, P. (2002); Antioxidant effect of Phaseolus vulgaris in streptozotoein-induced diabetic rats. Asia Pacific Journal of Clinical Nutrition, 11(3):206-209.

Tavares, R.L., Aquino, J.S., Silver, A.S., Campos, A.R.N. and Schuler, A.R.P. (2015). Nutritional composition, phytochemicals and microbiological quality of the legume, Mucuna pruriens. African Journal of Biotechnology, 14(8):676-682.

Theml, H., Diem, H., \& Haferlach, T. (2004); Color atlas of hematology. "Practical microscopic and clinical diagnosis" $2^{\text {nd }}$ ed, Munich, Germany, 7-128.

Toma, I., Karumi, Y., \& Geidam, M.A. (2009); Phytochemical screening and toxicity studies of the aqueous extract of the pods pulp of Cassia sieberiana DC. (Cassia Kotchiyana Oliv.). African Journal of Pure and Applied Chemistry, 3(2):026-030.
Trease, G.E., \& Evans, W.C. (1989); Pharmacognosy. 11th Edition. Brailliar. Tiridel Can. Macmillian.

Umaru, B., Saka, S., Mahre, M.B., Ojo, N.A., Dogo, H.M., \& Onyeyili, P.A. (2015). Acute toxicity and effects of aqueous pod extract of Acacia nilotica on some haematological parameters and body weight in rats. International Journal of Health and Medical Information, 4(3):3741.

Verhelst, G. (2010). Large manual medicinal plants. $4^{\text {th }}$ ed. BVBA Mannavita, 427-428.

Weiss, R.F., \& Fintelmann, V. (2000). Herbal medicine. $2^{\text {nd }}$ ed. Pub. Thieme Stuttgart, New York, USA, 128-129.

Wonghirundecha, S., Benjakul, S., \& Sumpavapol, P. (2014). Total phenolic content, antioxidant and antimicrobial activities of stink bean (Parkia speciosa Hassk.) pod extracts. Songklanakarin Journal of Science and Technology, 36(3):301-308. 